\title{
Improvement Of Internal Quality Assurance System Based On ISO 9001:2008 With Document Management Control (DMC) And Web Based Application
}

\author{
Hermien Tridayanti, Bayu Airlangga Putra , Ani Wulandari \\ Economic and Business Faculty, Narotama University, East Java-Indonesia \\ Email : hermien.tridayanti@narotama.ac.id, bayu.airlangga@narotama.ac.id, \\ ani.wulandari@narotama.ac.id
}

\begin{tabular}{|c|c||c|}
\hline $\begin{array}{c}\text { Accepted : } \\
\text { January, 07 2018 }\end{array}$ & Reviewed : & $\begin{array}{c}\text { Published : } \\
\text { Farch,30 2018 }\end{array}$ \\
\hline
\end{tabular}

\begin{abstract}
Purpose: This research aims is to produce the product in the form of Document Management Control application integrated with SIPENJAMU Narotama University Surabaya to meet the internal needs.

Design/methodology/approach: This research method using the development research design.

Findings: Create quality holistic cycles that work best with the uniqueness of the institution itself. This will then result in a "Competitive Advantage" for the institution.

Research limitations/implications: The implementation of internal control can only be done if the amendment to the accounting system as well as the separation of the functions necessary to anticipate the implications.

Practical implications: This research is also expected to contribute to the development of science that combines the concept of internal quality assurance, approach to business process realities in universities and combined with information technology and multi-media based on WEB applications.

Originality/value: The virtue of this proposed research is to make familiar with the use of integrated system with SIPENJAMU, so as to improve the performance of each Lecturer and Employee in performing their duties.
\end{abstract}

Paper type: contextual paper

Keyword: Internal Quality Assurance System, Information Technology, Integrated System and Competitive Advantage

\section{INTRODUCTION}

The development of the business world is accelerating, almost all business segments provide opportunities and challenges, including implications for the demanding needs of skilled workers with capabilities that meet the standards of professionalism. Higher Education as a producer of workforce is required to be able to respond by preparing facilities and infrastructures that are supported by the improvement of human resources capabilities in the field of Information Technology.(Cahyono, 2017; Tinovitasari, Yuliastanti and Malati, 2017; Wajdi, Ummah and Sari, 2017)

Learning from the existence of Quality Assurance System of Higher Education, since the year of educational reform with many make changes concerning system, culture and figure their manager. Changes that occur in between, the quality culture has a significant influence on changes in one's attitude. Initially, the internal quality management system that has been applied feels quite contribute to the changes needed.

Improvement Of Internal Quality Assurance System Based On ISO 9001:2008 With Document Management Control (DMC) And Web Based Application

Hermien Tridayanti, Bayu Airlangga Putra , Ani Wulandari 
However, with the growth and development of the organization, then decision-making that can be given quickly and appropriately has become a demand.

Approach of competence appropriately the principle can implicate the guarantee system internal quality has not been fully operational, in the sense that it is appropriate for a particular situation but not necessarily suitable for other situations. In addition, SIPENJAMU becomes rigid from the elements of adaptibility development, because it emphasizes the know how and less attention to know why. Therefore, both approaches, namely competency-based and broad-based approaches are accommodated. There are 4 main characteristics in the Curriculum: (1) simple, meaning only contains general principles that can be developed further; (2) flexible, in the sense can be tailored to the demands of needs; (3) is dynamic, can be developed continuously; and (4) relevance, must always be able to demonstrate good performance.

In the Implementation of the University's Internal Quality Assurance System, experience shows that despite its flexible and dynamic characteristics, but because it is designed and developed with the old paradigm, it is not conducive enough to accommodate the insights and missions contained in a new paradigm different from before, so it needs improvement effort. Therefore, by referring to the foundation, program and development of an internal quality assurance system that uses the basic principles, namely: (a) based on competence; (b) base-based and strong; (c) learning through direct experience, (d) self-study, (e) applying feedback and reinforcement.

The concept of the internal quality assurance system is the systemic activity of ensuring the quality of higher education in universities by the universities (internally driven), to oversee the implementation of higher education by universities themselves on a continuous basis (continuous improvement).

Furthermore, the main issue is how internal quality assurance system that has been implemented in SIPENJAMU will be further enhanced the quality of its use by adding Web-based Document Management Control application to accelerate decision making process both in academic and non academic scope.

\section{The relationship between ongoing and ongoing research}

Many use of integrated and ongoing system, even done by various circles in connection with performance achievements in Higher Education. On the other hand the development of information and multimedia technology comes so quickly, and even undeniably that the use of information technology has become a necessity for every human being today.

This research is intended to combine the concept and information technology that has been developed by Higher Education by combining the use of information technology with facilities. So that the operational process both in the academic and non academic can provide satisfactory service.

\section{Virtue, originality and anticipated contribution to performance improvement}

The virtue of this proposed research is to make familiar with the use of integrated system with SIPENJAMU, so as to improve the performance of each Lecturer and Employee in performing their duties. This research is also expected to contribute to the development of science that combines the concept of internal quality assurance, approach to business process realities in universities and combined with information technology and multi-media based on WEB applications.

\section{Targeted outcomes}

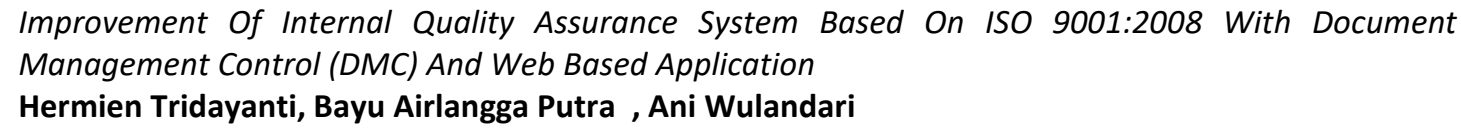


With the guidance is expected activities of preparation and activities associated with SIPENJAMU can be done and monitored wherever the user is located, so as to optimize the performance achievements of individuals and related units. among others :

1. The existence of infrastructure in the form of Document Management Control application will be very useful in improving the performance in academic and non academic scope. With the use of this method will also familiarize the use of the online environment that is now a basic technical skill, where each lecturer and personnel personnel will be familiar with the process of searching, receiving \& transmitting data and utilize the data available on the WEB.

2. Establishment of Management Performance with the integration of practice management in which there are assessments of employees, including the determination of performance standards and ensure organizational goals can be achieved.

\section{Contribution to science}

The expected contribution to science is the development of the Internal Quality Assurance System of Narotama University which consists of:

1. Establishment of sub-systems that have been integrated with SIPENJAMU (Quality Assurance System) Narotama University.

2. The establishment of Standard Operating Procedure (SOP) and Work Instruction (WI) based on Web Application and Document Management Control.

3. The realization of WEB Document Management Control application as media learning.

Quality Management System Principles ISO 9001: 2008 Based on IWA 2: 2007

In a quality management system referred to ISO 9001: 2008 as a general requirement the organization shall establish, document, implement and maintain the quality management system and continuously improve its effectiveness in accordance with the requirements of the standards, in which the organization shall:

1. Establish the processes required in the quality management system and apply them across units within the organization.

2. Define the sequence and interaction of the process.

3. Define the criteria and methods needed to ensure the operation and control of the process effectively.

4. Ensure the availability of resources and information necessary for the operation and monitoring of the process.

5. Monitor, measure and analyze the process.

6. Take necessary action to achieve results consistent with ongoing planning and improvement.

Guidelines ISO 9001: 2008 Based on IWA 2: 2007 in clause 4.2.3 the purpose of document control is to ensure that all documents contained in the quality management system are continuously updated and available only in the current version. Educational institutions should establish documented procedures for:

1. Edit, review in internal documents, including identification and revision status.

2. Control of external documents, preferably relevant to the regulations, which should always be updated.

3. Ensure that documents are available to all personnel at organization.

4. Manage and control ownership documents from customers.

5. Ensuring graduation tracking as one of the services provided by the organization.

6. Verify compliance of the requirements in the stages of the process.

Improvement Of Internal Quality Assurance System Based On ISO 9001:2008 With Document 
Effectiveness of Application Use Document Management Control

Web-based Document Management Control application synergized with ISO 9001: 2008 Standard Based on IWA 2: 2007 comprising:

1. Module preparation of Document Management Control and adjustment to the requirement of mastery of computer technology as sufficient condition to support performance of adjustment to reporting mechanism, both from academic unit and non academic.

2. Establishment of Standard Operation Procedure (SOP) related to the use of the application, made Work Instruction (WK) for any work unit can access it.

3. Document Control Application Document-Based Document Management Component consists of:

a. Metadata

Represents the data contained in the document, usually as a property of the document. Metadata can be inputted manually or automatically generated by the program, for example: document creation date, document classification, etc.

b. Integration

Most document management systems attempt to integrate document management with other applications to make it easier for users to change, add, delete, and save as new versions without having to exit the application.

c. Capturing Storage of images from a document using a scanner or OCR.

d. Indexing The numbering system of documents, so that documents are easy to find and identified.

e. Storage

Document storage, usually the required hard drive capacity, and system back up.

f. Retrieval

The retrieval of documents and methods performed to edit or delete documents by the author of the document concerned.

g. Distribution

Distribution of documents, distribution control to get to the right people can be through several ways.

h. Security

Security created against these documents, protection and control of the distribution of documents and maintaining the authenticity of documents.

i. Workflow

Document management systems should build workflow modules. There are several types of workflows, where their use depends on the proposed e-DMS environment. Manual workflow required the user to view the document and decide to whom the document will be sent. The basic rules of the workflow allow the admin to create rules that govern the flow of documents within the organization.

\section{METHODOLOGY}

This research is conducted by applying the development research design with the aim to produce the product in the form of Document Management Control application integrated with SIPENJAMU Narotama University Surabaya to meet the internal needs.

\section{DMC TRIAL TEST LIMITED}

Improvement Of Internal Quality Assurance System Based On ISO 9001:2008 With Document 


\section{FEED BACK ANALYSIS OF TRIAL}

\section{DMC TESTS}
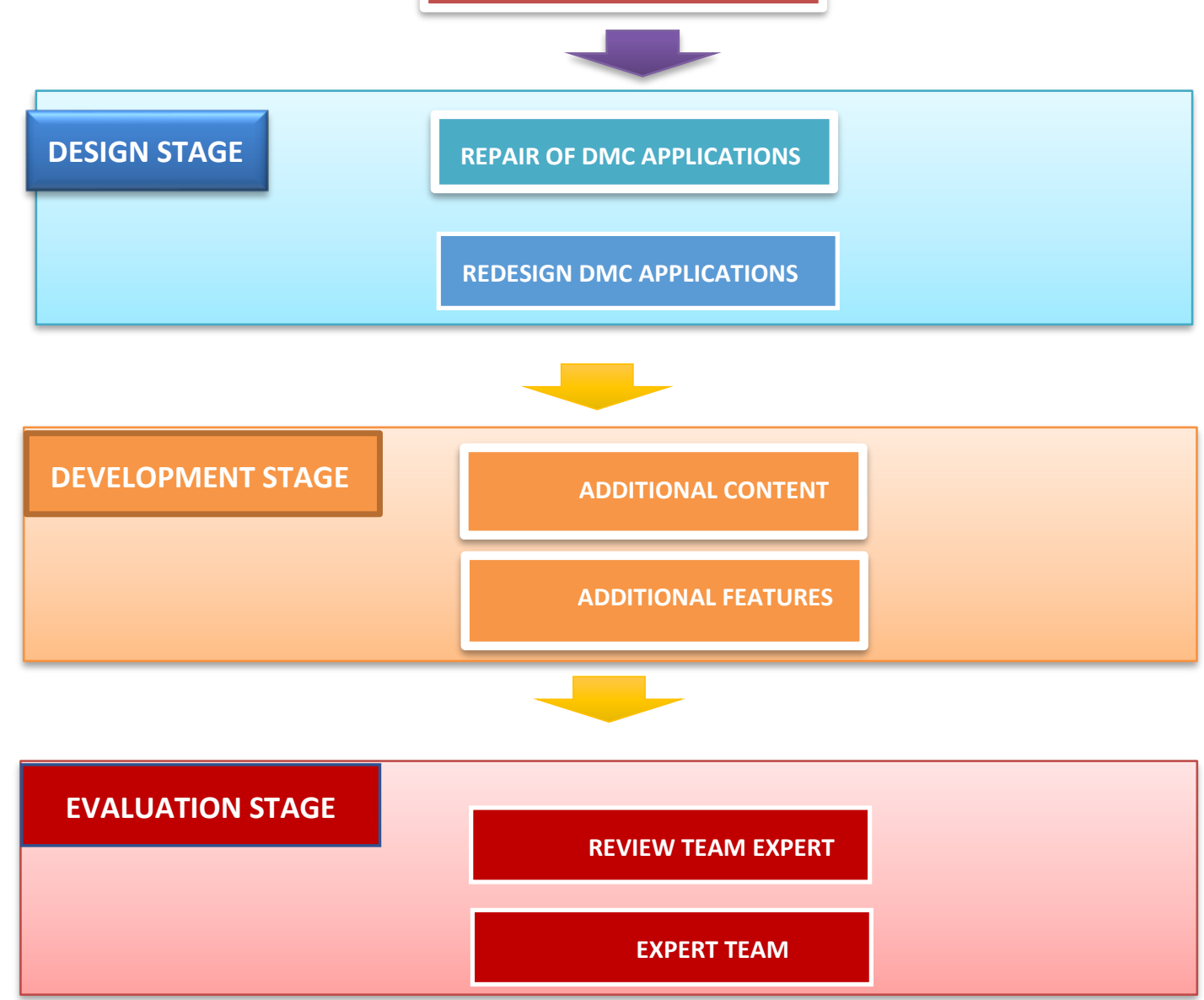

Figure 1. Flow Chart Document Management Control

\section{Involvement In The Process Of Developing Internal Quality Assurance System}

Development of SIPENJAMU based Document Management Control requires experts in content, andragogy, technical and manufacturing aspects, so that a multi-disciplinary team-based approach is needed.

This research is based on the development research design with the implementation procedure grouped into two stages. The study design is as follows:

1. The first phase was developed survey design and development design through brainstorming and focus group disscusion.

2. The second stage, research development and experimental research with the design of Document Management Control, is a web-based application.

Meanwhile, for the preparation of synchronization of Document Management Control materials relevant to the needs of Higher Education, selection of documentation flow, and integration with the ISO

Improvement Of Internal Quality Assurance System Based On ISO 9001:2008 With Document 
9001: 2008 based quality management system on IWA 2: 2007, and the preparation of SOP Based on Interactive Computer Simulation and Web Applications oriented competence relevant skills are done with reference to the 4D model, which includes define, design, develop, and disseminate.

Define stage is basically the stage of determining the format and substance of the product to be prepared (document mapping, arranging the flow of document distribution). In this case is done through three sub-stages, namely:

1. Phase Needs analysis (need analysis).

2. Phase Development analysis (development analysis).

3. Experimental assessment stage (expert judgment).

Needs analysis conducts field survey and initial design, with close attention to the internal mailing flow of the Narotama University system for synchronizing relevant material and with operational needs. Second, the analysis of development (development analysis) is making the design of the flow of documentation based on the requirements that exist in ISO 9001: 2008 based on IWA 2: 2007. The results of the two methods are then combined, resulting in a document management control that can provide clarity of communication flow along with supporting documents, which will speed up the decision-making process. To ensure compliance with performance outcomes that have been determined, reviewed in focus group discussions and continued with expert judgment.

Expert judgment stage, Experts involved in focus group discussions and expert judgment are experts in various fields, including higher education, internal quality assurance system and information and communication technology. Thus in the defining phase (define) will be generated basic framework of research products that have been through the discussion phase, including: format, SOP, and work instructions are synchronous and relevant to the internal mailing system Narotama University.

\section{DISCUSSION}

Based on the basic framework then forwarded to the development stage, namely the making of standard operation procedure (SOP) and Work Instruction (WK) based Document Management Control with Web applications.

The expert review stage is intended to gain input on the adequacy of the design developed by researchers based on the needs of the internal quality assurance system. In addition, this step is intended to obtain validation about:

1. Adequacy of design

2. Document distribution flow

3. Relevance of content contained in Document Management Control

4. The quality of the layout is consistent with the indicators used in the review then the experts involved in this activity include: information technology, quality assurance, and universities.

Next performed a trial of Document Management Control that has been compiled. At this stage the research product is actually nearing the final. Nevertheless, to obtain empirical evidence that the research product has been feasible then some of the research product is tested by system which exist in internal mailing system in all units both in academic and non academic (disseminate stage). Implementation of trials conducted by doing data entry on Document Management Control, then performed an analysis of a process in SOP in each unit Academic and Non Academic.

Improvement Of Internal Quality Assurance System Based On ISO 9001:2008 With Document 


\section{CONCLUSION}

In addition to the method of preparing and preparing the above SOP, it is also necessary to do staff development at the implementation stage, to facilitate and facilitate the course of change from the traditional course into Interactive Computer and Web Applications.

In this research can be concluded as follows:

1. Document Management Control application can be a support for operational process, this can be seen from lay out DMC which accelerate to know existence of a document.

2. The DMC application strongly supports the quality management system, whereby all documents will be distributed if approved by the document holder.

3. In this research based on ISO 9001: 2008 Quality Management System based on IWA 2: 2007, in the second year plan will be updated to ISO 9001: 2015. So the DMC will be adjusted to the requirements of document distribution, both academic and non academic.

\section{REFERENCES}

Anstine, J. (2013). Graduation rates at U.S colleges and universities: a large data set analysis. Business Education \& Accreditation, 5(2), 55-64. Barney, J. B. (1991). Firm resources and sustained competitive advantage: Journal of management, 17(1), 99-120.

Bobe, B. J. (2012). Management control systems, strategy implementation and capabilities development in university academic units: impacts on performance (Doctoral dissertation, RMIT University). Retrieved from https:// researchbank.rmit.edu.au/eserv/rmit:160082/ Bobe.pdf Fairholm, M. R. (2009). Leadership and organizational strategy.

Cahyono, H. (2017) 'Abnormal Return Differences Before And After Amnesty Tax Policy 2016-2017 Period II And III (Event Study at Company divided in LQ45 Index)', IJEBD (International Journal Of Entrepreneurship And Business Development), 1(1), pp. 39-74.

The Innovation Journal: The Public Sector Innovation Journal, 14(1), 3-16. Hair, J. F., Black, W. C., Babin, B. J., \& Anderson, R. E. (2010). Multivariate data analysis: A global perspective (7th ed.). Upper Saddle River, NJ: Pearson Education.

Herlambang, T., Afnan T, E., Sudiro, A., \& Noermijati. (2013). Analysis of Competitive Advantage in the perspective of Resources Based View. IOSR Journal of Business and Management (IOSRJBM), 10(1), 30-49.

Retrieved from www. iosrjournals.org Hidayat, D.S. (2008). Strategi Membangun Kompetensi Organisasi Dalam Rangka Meningkatkat Kinerja Penguruan Tinggi Swasta (PTS) Di Jawa Tengah. (Tesis, Program Pacasarjana). Universitas Diponegoro

Hill, Y., Lomas, L., \& MacGregor, J. (2003). Students' perceptions of quality in higher education. Quality Assurance in Education, 11(1), 15-20. doi: 10.1108/09684880310462047

Hinton, K. E. (2012). A practical guide to strategic planning in higher education. Ann Arbor, MI: Society for College and University Planning. Jenita, J. (2014). Analisis Pengaruh Motivasi Dan Pelaksanaan Strategi Sdm Terhadap Kinerja Dosen Serta Implikasinya Pada Kualitas Lulusan (Survey pada PTS di Provinsi Riau). Jurnal Ilmiah Ekonomi dan Bisnis, 11(2), 482-510.

Kandiko, C. B., \& Mawer, M. (2013). Student expectations and perceptions of Higher Education. London: King's Learning Institute. Kiptoo, K. K., \& Mwirigi, F. M. (2014). Factors That Influence

Improvement Of Internal Quality Assurance System Based On ISO 9001:2008 With Document 
Effective Strategic Planning Process In Organizations. IOSR Journal of Business and Management (IOSR-JBM), 16(6), 188-195.

Mason, G., Williams, G. C., \& Cranmer, S. (2009). Employability Skills Initiatives in Higher Education: What Effects Do They Have on Graduate Labour Market Outcomes? Education Economics, 17(1), 1-30. doi: 10.1080/09645290802028315

Messah, O. B., \& Mucai, P. G. (2011). Factors Affecting the Implementation of Strategic Plans in Government Tertiary Institutions: A Survey of Selected Technical Training Institutes.

European Journal of Business and Management, 3(3), 85-105. Morgan, S. L. L. (2011). Strategic planning and leadership: renewing the relationship to reclaim the rewards. Cuadernos Latinoamericanos de Administración, 7(12), 9-20.

Narimawati, U. (2008). Peranan Modal Intelektual Dosen dalam Menciptakan Kualitas Lulusan. Majalah Ilmiah Unikom, 6(2), 143-156. OECD Publishing. (2010). Learning Our Lesson: Review of Quality Teaching in Higher Education. OECD Pub.

Quality Management Systems Requirements, ISO 9001:2008. Badan Standarisasi Nasional (BSN).

Pesic, M. A., Milic, V. J., \& Stankovic, J. (2012). Application of VRIO Framework for Analyzing Human Resources Role in Providing Competitive Advantage. In Proceedings of the Tourism and Management Studies International Conference Algarve (pp. 575-586).

Powers, J. B., \& McDougall, P. P. (2005). University start-up formation and technology licensing with firms that go public: a resource-based view of academic entrepreneurship. Journal of Business Venturing, 20(3), 291-311.

Prasetyaningrum, I. D. (2009). Analisis Pengaruh Pembelajaran Dan Kualitas Pelayanan Terhadap Kepuasan Mahasiswa Dan Loyalitas Mahasiswa (Studi Kasus Pada Undaris Ungaran (Master's thesis). Universitas Diponegoro, Semarang, Indonesia.

Sadiq, M. A. (2014). Transformational leadership, knowledge management, entrepreneurial orientation and organisational excellence in the higher education institutions in Nigeria (Doctoral dissertation). Universiti Utara Malaysia, Sintok, Kedah, Malaysia.

Tinovitasari, F., Yuliastanti, R. and Malati, F. (2017) 'Work Discipline Factors Affecting Employees Performance Of Marketing Subdivision of Madika Foundation In Surabaya', IJEBD (International Journal Of Entrepreneurship And Business Development), 1(1), pp. 23-38.

Wajdi, M. B. N., Ummah, Y. C. and Sari, D. E. (2017) 'UKM Development Business Loan. IJEBD (International Journal Of Entrepreneurship And Business Development), 1 (1), 99-109'.

Retrieved from http://etd.uum. edu.my/4499/ Samson, D., \& Terziovski, M. (1999). The relationship between total quality management practices and operational performance. Journal of Operations Management, 17(4), 393-409. doi: 10.1016/ S0272-6963(98)00046-1

Sumardjoko, B. (2010). Faktor-Faktor determinan Peran Dosen Dalam Penjaminan Mutu Perguruan Tinggi. Cakrawala Pendidikan, 3(3), 294-310. Thoyib, A. (2005) Hubungan Kepemimpinan, Budaya, Strategi, dan Kinerja: Pendekatan Konsep. Jurnal manajemen dan kewirausahaan, 7(1) 60-73.

Theresa Thonhauser, 2006. ISO 9000 in Education: a comparison between the United States and England. Research in Comparative \& International Education, Vol. 1, No. 2, 2006 doi: 10.2304/rcie.2006.1.2.156 
Wright, P. M., Dunford, B. B., \& Snell, S. A. (2001). Human resources and the resource based view of the firm. Journal of Management, 27(6), 701-721. doi: 10.1016/S0149-2063(01)00120-9

\section{ATTACHMENTS}




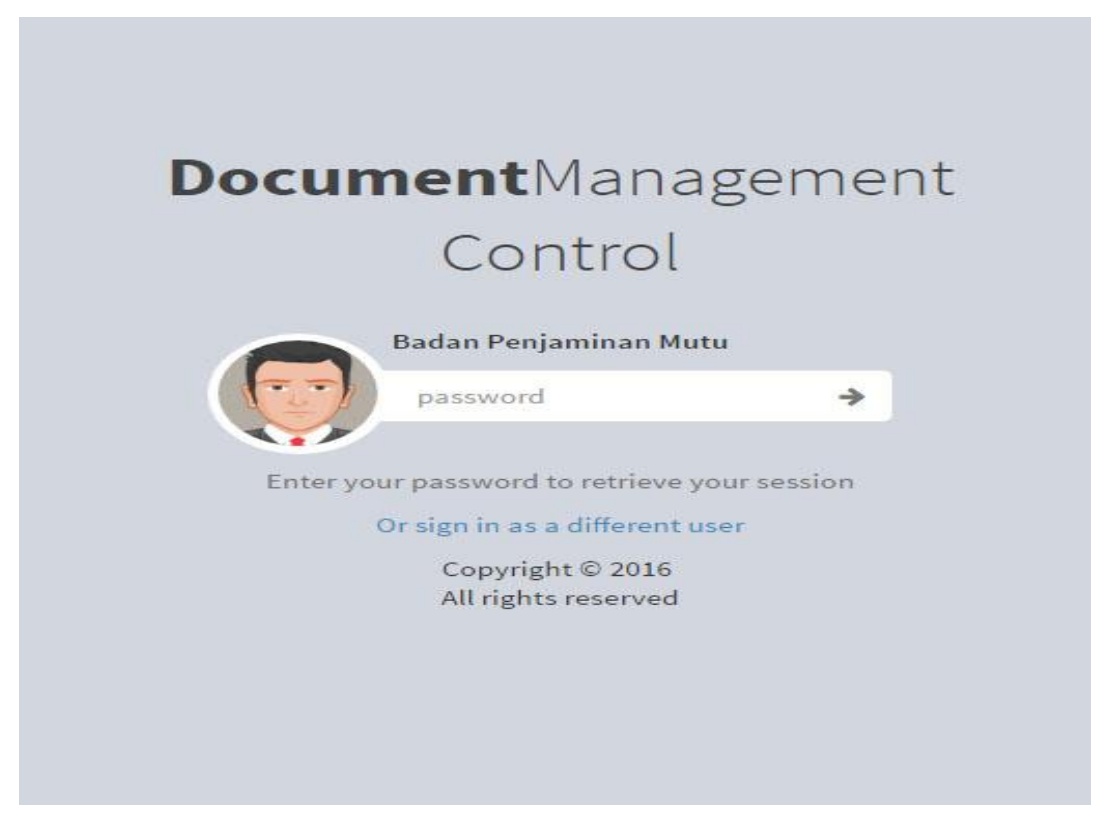

Figure 1. Preview Document Management Control

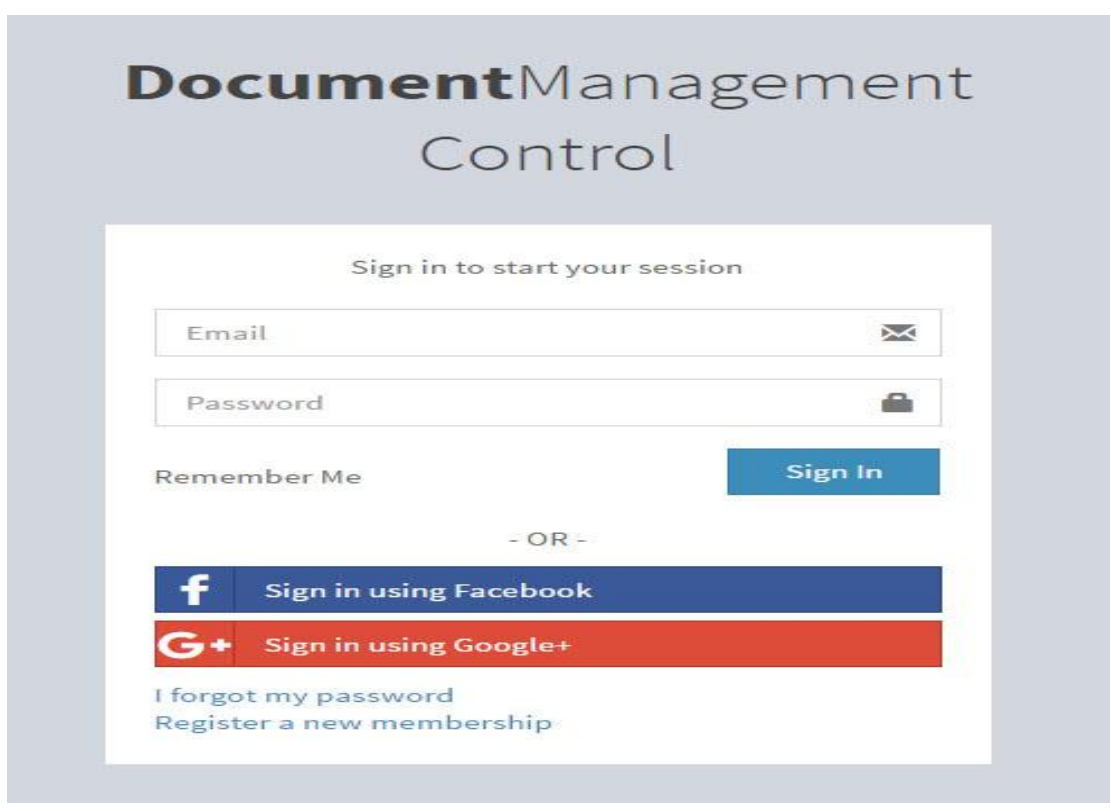

Figure 2. Login Document Management Control

Improvement Of Internal Quality Assurance System Based On ISO 9001:2008 With Document Management Control (DMC) And Web Based Application

Hermien Tridayanti, Bayu Airlangga Putra , Ani Wulandari 


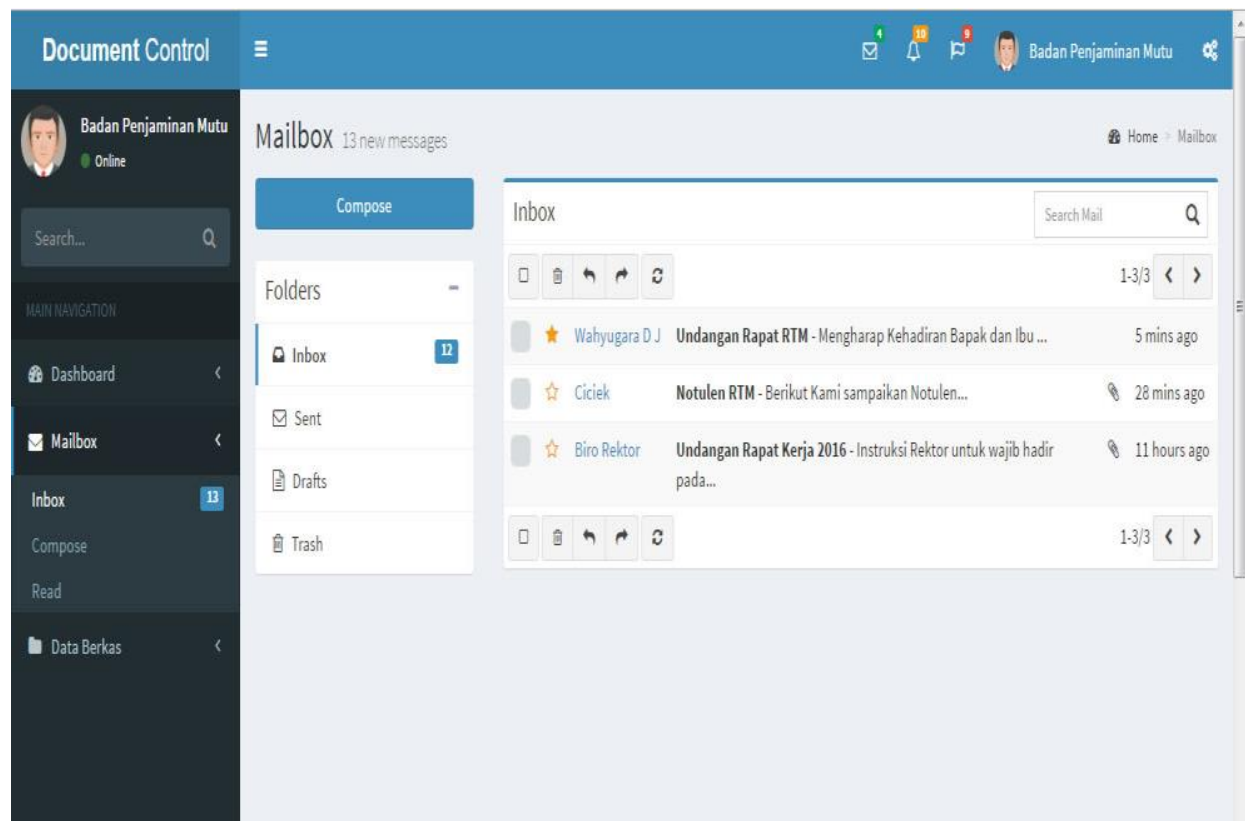

Figure 3. Mailbox Document Management Control

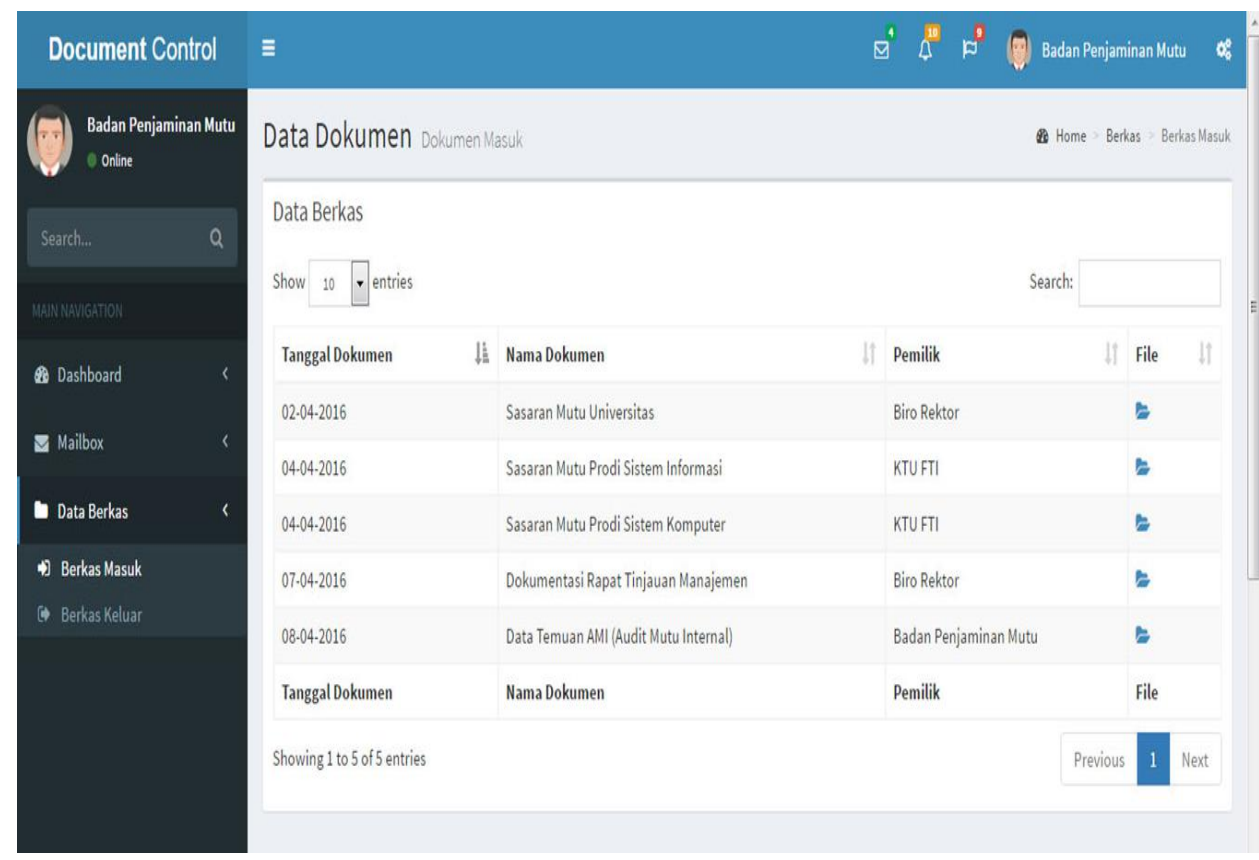

Figure 4. Incoming Document Management Control

Improvement Of Internal Quality Assurance System Based On ISO 9001:2008 With Document Management Control (DMC) And Web Based Application Hermien Tridayanti, Bayu Airlangga Putra , Ani Wulandari 


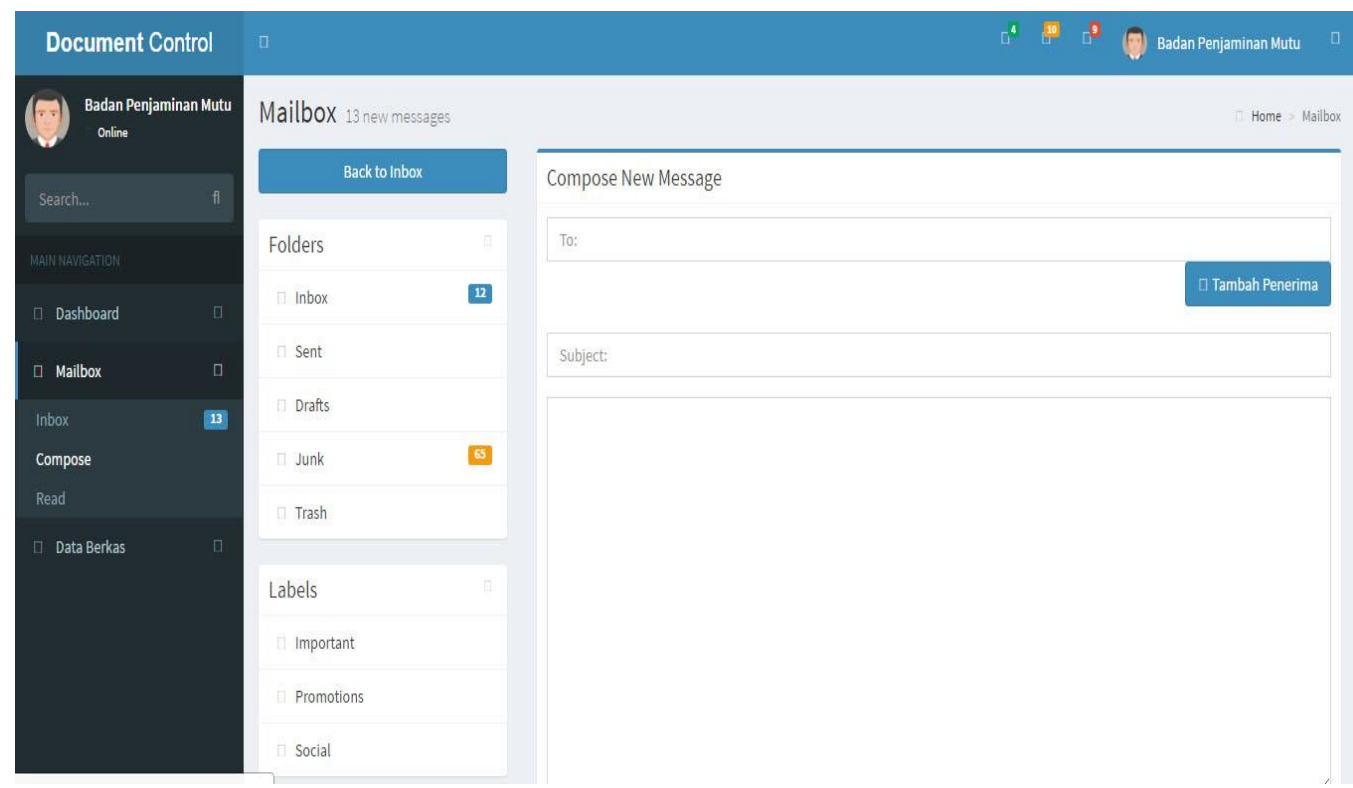

Figure 5. Compose Message Document Management Control

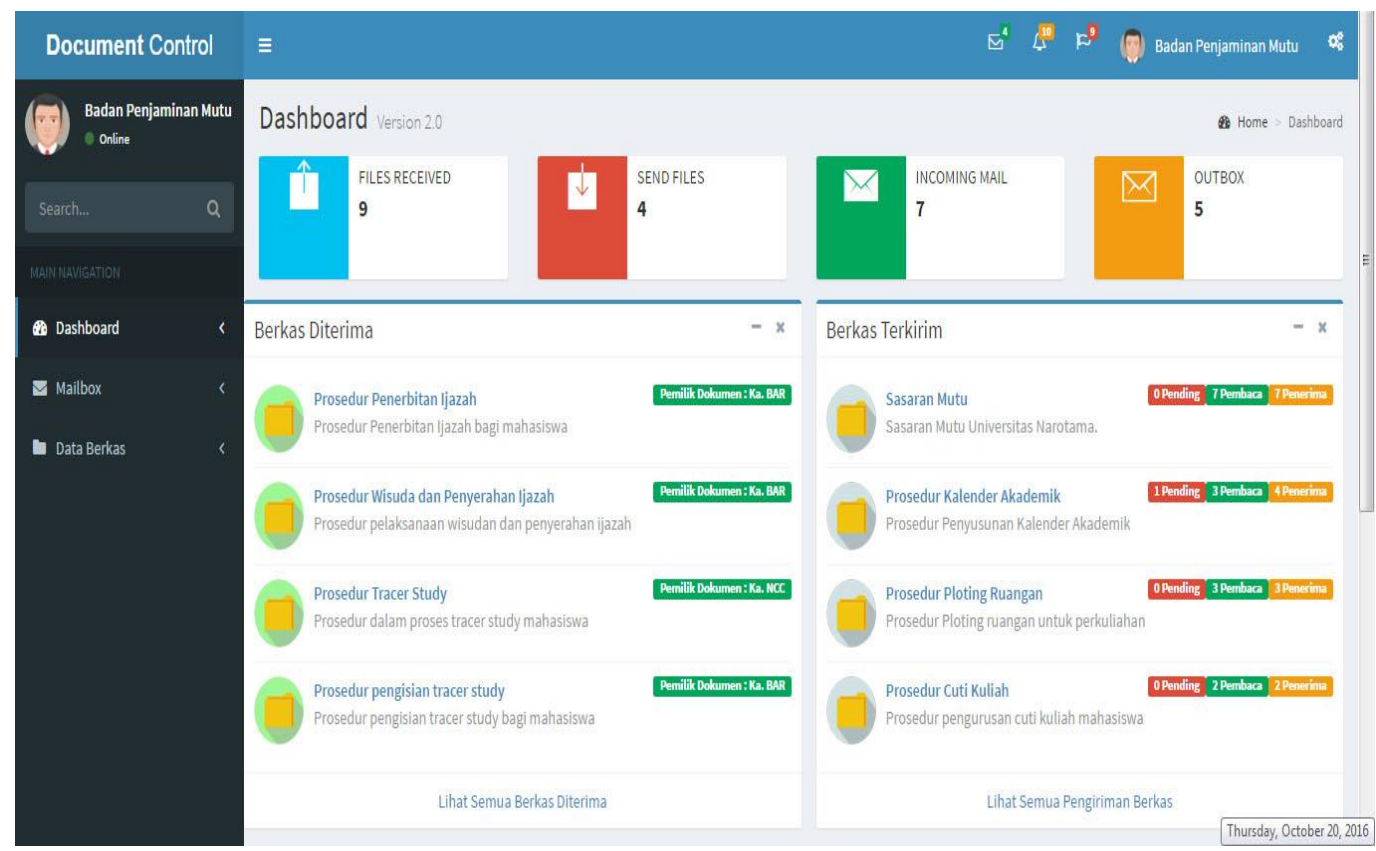

Figure 6. Dashboard Document Management Control

Improvement Of Internal Quality Assurance System Based On ISO 9001:2008 With Document Management Control (DMC) And Web Based Application Hermien Tridayanti, Bayu Airlangga Putra , Ani Wulandari 